\title{
WATER STRESS AND THE EFFECTIVE MANAGEMENT OF WATER IN THE HEALTHCARE SECTOR
}

\author{
Shyamala Mani, Samayita Ghosh and R. Srinivasan
}

\section{Introduction}

The impacts of climate change can be manifested through changing patterns of water availability. Given that water and weather are closely linked through evaporation and precipitation, any alteration in the balance between the two can cause an erratic rise in droughts, floods, humidity, glacial melt and rise in sea level. Increased flood discharge of surface water, as well as frequent droughts, are not congenial for the groundwater recharge that supports the maintenance of the water table, which sustains base flow in rivers. Increasing demand for water, including groundwater exploitation, exacerbates the water crisis and seasonal irregularities in the availability patterns (Payus et al., 2020). This chapter examines:

1. The aspect of water stress, especially in the health sector, as a function of availability of safe water in terms of quantity and quality, a key constituent to healthcare operations in various healthcare establishments.

2. The urgent need for efficient management to ensure continuity in access, reduction in wastage and overconsumption.

\section{Understanding water quantity and quality in the Indian context}

In terms of water quantity, India has about $4 \%$ of global water resources with a per capita availability of 1086 cubic meters annually, which is projected to go down to 760 cubic meters by 2050 , indicating surmounting deficits over the years. India supports $16 \%$ of the world's population and $15 \%$ of livestock with $66 \%$ of its 1.38 billion population being rural. There is also a considerable gap in the development and management of water resources between urban and rural areas. Going by per capita availability, India has been ranked among the countries which are extremely water stressed, with the intensity varying regionally and seasonally (Hofste et al., 2019).

Currently, the total utilizable water resources in the county is about 1123 billion cubic meters ( $\mathrm{bcm}$ ) with $690 \mathrm{bcm}$ of surface and $433 \mathrm{bcm}$ of groundwater resources, replenished and recharged by total rainfall of about 
$4000 \mathrm{bcm}$. Almost $90 \%$ of the groundwater is utilised for irrigation needs; the remaining $10 \%$ supplies about $85 \%$ of the country's drinking water. As against a requirement of $70 \mathrm{~L}$ per capita per day (lpcd) of water, the current provision is only about $40 \mathrm{lpcd}$, even though the coverage of population with access to improved sources of drinking water has increased manifold since independence (CWC, 2019). While the National Rural Water Supply Mission is committed to providing safe water to even the remotest of villages, Jal Shakti Abhiyan has taken up addressing the problem of water shortage in 255 water stressed districts of the country.

Water quality refers to the physical, chemical, biological and radiological characteristics of water with the usability of freshwater being assessed against standardised parameters. ${ }^{1}$ Almost $70 \%$ of the country's surface water and an increasing quantum of its groundwater are contaminated with toxic elements that are bio-accumulative and carcinogenic, rendering serious health hazards on humans, flora and fauna. The toxicity of water, measured against acceptable and permissible levels of various constituent elements point at several geogenic and anthropogenic factors. Co-occurrence of contaminants is usually characterised by a combination of these factors, although in some cases anthropogenic activities, such as infiltration of organic and nitrate-rich water, may contribute to the persistence and enhanced mobilisation of geogenic contaminants (Coyte et al., 2018).

Poor waste management, disposal and discharge wastewater emanating from domestic and industrial settings are some of the anthropogenic factors or human activities that contribute to water pollution. Wastewater emanating from water-intensive chemical, distillery, food, dairy and beverage, pulp and paper, sugar, textile, bleaching and dying, tannery and other industries produce 501 million litres of wastewater per day, while there are treatment facilities only for 193 million litres (National Green Tribunal Status Report, 2019). The lack of sewage disposal facilities, especially in the rural context, has led to anthropogenic surface water pollution. Open defecation, infiltration of pollutants from industrial discharge, non-compliance with standards by stakeholders, and indiscriminate use of pesticides are some of the main causes for groundwater contamination.

Naturally occurring or geogenic contaminants manifest by elevated levels of arsenic, fluoride, nitrate, total dissolved solids, chloride and iron often seen in groundwater. Arsenic contamination is predominant in the Ganga and Brahmaputra valleys in West Bengal, Assam, Chhattisgarh, Bihar and Uttar Pradesh. Fluoride contamination is more widespread in the country, especially in the arid and semi-arid belts. Total dissolved solids as indicated by electrical conductivity, contribute to hardness of water and salinity, which is dominant in the coastal and arid belts. Of late, higher concentrations of uranium have been reported from groundwater in Punjab, Gujarat, Rajasthan, Andhra Pradesh, Tamil Nadu, and a few eastern districts of Karnataka (Coyte et al., 2018). 


\section{Disease burden}

Extreme events such as floods and droughts are associated with outbreaks of communicable diseases and some chronic conditions. During periods of heavy rainfall and flooding, the capacity of water treatment plants may prove inadequate, and there may be contamination of drinking water with sewage; especially where water supply infrastructure is old, sewage can overflow and contaminate local waterways. Droughts or extended dry periods are known to reduce the volume of river flow and reduce the dilution of concentration of effluents (Cann et al., 2013).

The concentration of dissolved chemicals in water is controlled by soilwater and rock-water interaction, both of which are controlled by climatic conditions which influence the $\mathrm{E}_{\mathrm{h}}$ (redox potential) and $\mathrm{pH}$ (potential of hydrogen ion) of water passing through the pores and cracks in soil and rocks. Droughts are also associated with food insufficiency, reduced nutrition and calorific intake, as well as compromised sanitation and hygiene, leading to low nutritional uptake as consequences of poor gastrointestinal performance. Diseases from water can arise because of chemical and biological contamination, both being climate sensitive.

Moreover, there is an increased risk of infection of water-borne diseases contracted through direct contact with polluted waters, such as wound infections, dermatitis, conjunctivitis, and ear, nose and throat infections. The epidemic infection which can be transmitted directly from contaminated water is leptospirosis, a zoonotic bacterial disease. Transmission occurs through contact with water, damp soil or vegetation (such as sugarcane) or mud contaminated with rodent urine on the skin and/or mucous membranes. The occurrence of flooding after heavy rainfall facilitates the spread of the organism due to the proliferation of rodents which shed large amounts of leptospirosis in their urine. Similarly, in the case of vector-borne diseases, flooding may initially flush out mosquito breeding, but it comes back when the floodwaters recede. The lag time in such cases is usually around 6-8 weeks before the onset of malaria epidemic (National Health Portal, Govt. of India, 2018). Annually, about 37.7 million Indians are affected by waterborne diseases, 1.5 million children die of diarrhoea and 73 million working days are lost leading to an economic burden of $\$ 600$ million a year. Waterborne diseases such as cholera, acute diarrhoeal diseases, typhoid and viral hepatitis continue to be prevalent in India and have caused 10,738 deaths over the last five years. Of this, acute diarrhoeal diseases caused maximum deaths followed by viral hepatitis, typhoid and cholera (Kelkar, 2019).

Moreover, exposure to contaminated water from surface and sub-surface sources is mediated through various primary and secondary activities that involve direct and indirect ingestion or dermal contact. The adverse health effects due to exposure to elevated levels of chemicals and heavy metals in water varying regionally are tabulated in Table 15.1. 
Table 15.1 Toxin standards and associated health effects

\begin{tabular}{|c|c|c|c|}
\hline $\begin{array}{l}\text { Chemical } \\
\text { constituent }\end{array}$ & $\begin{array}{l}\text { Drinking } \\
\text { water standard } \\
\text { set by BIS } \\
10500(2012) \\
\text { in } \mathrm{mg} / \mathrm{L}\end{array}$ & $\begin{array}{l}\text { Drinking } \\
\text { water } \\
\text { standard set } \\
\text { by WHO } \\
\text { (2011) } \mathrm{mg} / \mathrm{L}\end{array}$ & $\begin{array}{l}\text { Health effects when } \\
\text { concentrations exceed the } \\
\text { permissible limit }\end{array}$ \\
\hline Arsenic & 0.05 & 0.01 & $\begin{array}{l}\text { Skin lesions, keratosis, backfoot } \\
\text { disease, basal cell carcinoma, } \\
\text { squamous cell carcinoma } \\
\text { Hepatotoxicity or liver diseases } \\
\text { hypertension, cardiomyopathy }\end{array}$ \\
\hline Chromium & 0.05 & 0.05 & $\begin{array}{l}\text { Hexavalent chromium causes } \\
\text { dermatitis, ulcers and cancer }\end{array}$ \\
\hline Fluoride & 1.5 & 1.5 & $\begin{array}{l}\text { Below } 0.5 \mathrm{mg} / \mathrm{L} \text { causes dental } \\
\text { caries; } 0.5-1.5 \mathrm{mg} / \mathrm{L} \text { desirable; } \\
1.5-3 \mathrm{mg} / \mathrm{L} \text { causes dental } \\
\text { fluorosis; } 3.1-6 \mathrm{mg} / \mathrm{L} \\
\text { osteoporosis; } 20 \text { to } 80 \mathrm{mg} \text { per } \\
\text { day through air and water } \\
\text { - crippling skeletal fluorosis; } \\
50 \mathrm{mg} / \mathrm{L} / \text { per day causes thyroid } \\
\text { changes; } 100 \mathrm{mg} / \mathrm{L} / \text { day retards } \\
\text { growth; more than } 125 \mathrm{mg} / \mathrm{L} \\
\text { causes kidney damage. }\end{array}$ \\
\hline Iron & 0.3 & & $\begin{array}{l}\text { At low levels good for health; } \\
\text { beyond } 0.3 \text { undesirable as it can } \\
\text { lead to haematochromatosis. } \\
\text { Total iron and manganese } \\
\text { should not exceed } 0.3 \mathrm{mg} / \mathrm{L} \text {. } \\
\text { Water also tastes bad when Fe, } \\
\text { Mn are high }\end{array}$ \\
\hline Selenium & 0.01 & 0.01 & $\begin{array}{l}\text { Selenium deficiency in human } \\
\text { body can cause gastrointestinal } \\
\text { disturbances, discoloration of } \\
\text { the skin and decay of teeth; it } \\
\text { can also cause Keshan disease } \\
\text { (multifocal myocarditis) or } \\
\text { chondrodystrophy (also called } \\
\text { Kaschin-Beck disease). Higher } \\
\text { selenium concentrations can } \\
\text { lead to higher risk of coronary } \\
\text { heart disease }\end{array}$ \\
\hline Uranium & & 0.015 & Liver damage and cancer \\
\hline $\begin{array}{l}\text { Nitrate } \\
\text { especially } \\
\text { nitrite }\end{array}$ & 45 & 50 & $\begin{array}{l}\text { At levels higher than threshold } \\
\text { gives rise to } \\
\text { methaemoglobinamia }\end{array}$ \\
\hline
\end{tabular}




\section{Water consumption patterns in the health sector}

(a) Consumption: Water consumption can be mapped in terms of utilisation and wastage within a sector. According to the Bureau of Indian Standards, hospitals with more than 100 beds need on an average, 450 $\mathrm{L} /$ head/day (equating to $164,250 \mathrm{~L}$ of water/head/year); those hospitals which have less than 100 beds require 340 Litres per head/day (see Table 15.2). However, according to an audit conducted by the Comptroller and Auditor General, $36 \%$ of the primary healthcare facilities forming an important constituent of rural health infrastructure have no access to this quantity of clean water.

(b) Uses: Water is an important resource for the healthcare sector to meet its daily operational needs that pertain to infection prevention and control activities and engineering functions. Any disruption in water supply may result in seriously compromising hand-washing and hygiene, drinking, food preparation, flushing of toilets and bathing the patients, laundry, cleaning and sterilisation of surgical instruments, reprocessing of medical equipment, patient care (haemodialysis, hemofiltration, extracorporeal membrane oxygenation, hydrotherapy), fire suppression sprinkler systems, water-cooled medical gas and suction compressors, HVAC and decontamination.

(c) Implications of water insufficiency: Unhygienic environment with inadequate supply of running water, hand washing facilities and poorly maintained or dysfunctional toilets, may lead to several adverse hospital outcomes. For instance, women may avoid or delay seeking care and are likely to leave such facilities sooner than they should after

Table 15.2 Water requirements for buildings in the health sector

\begin{tabular}{llcc}
\hline & $\begin{array}{l}\text { Domestic } \\
\text { Litres per } \\
\text { head/day }\end{array}$ & $\begin{array}{l}\text { Flushing } \\
\text { Litres per } \\
\text { head/day }\end{array}$ & $\begin{array}{l}\text { Total Consumption } \\
\text { Litres per head/day }\end{array}$ \\
\hline $1 \quad \begin{array}{l}\text { Hospital (excluding } \\
\text { laundry and kitchen): } \\
\text { a) Number of beds not } \\
\text { exceeding 100 }\end{array}$ & 230 & 110 & 340 \\
$\begin{array}{l}\text { b) Number of beds } \\
\text { exceeding 100 } \\
\text { c) Out Patient } \\
\text { Department (OPD) }\end{array}$ & 300 & 150 & 450 \\
$\begin{array}{c}\text { Nurses' homes and } \\
\text { medical quarters }\end{array}$ & 10 & 5 & 135 \\
\hline
\end{tabular}

Bureau of India Standards, 2012 
delivery, resulting in inadequacies in maternal and child health care. Sepsis, a hospital borne infection, accounts for $11 \%$ of maternal deaths in India, with the highest rate in Southern Asia (13.7\%). In places with high mortality such as India, up to $50 \%$ of neonatal deaths are due to infections, with $30-40 \%$ of infections that result in fatal neonatal sepsis transmitted at the time of birth (Water Aid India, 2005). SARS CoV $1 \& 2$, MERS and several other diseases such as diarrhoea and acute respiratory tract infections (ARIs) can be prevented and their transmission effectively reduced through frequent handwashing practices.

(d) Implications of elemental presence: Use of iron-rich water in hospital laundries turns the bed linen yellow or yellow brown after a couple of washes. Groundwater with high concentrations of total dissolved solids (TDS) and salinity is hard and is also not suitable for hospital laundry. It is not uncommon to see stained toilet bowls and bathroom floors and scaling on taps and flush tanks in public health facilities, which are a result of the use of such iron $(\mathrm{Fe})$ rich hard water. The hard water can clog the pipes and or corrode them. They can deposit the salts and corrode sterilisation units. It is not known as to how many health care centres are provided with ultraviolet lamp fitted reverse osmosis units (UV-ROs) to generate adequate amounts of water free of biological and metal contaminants and safe for drinking required in patient care and the maintenance of hospital equipment (Box 15.1).

\section{Wastewater in the health sector}

Healthcare organizations generate high strength sewage ${ }^{2}$ and wastewater, and are prone to variable flows and loads due to changing patient and visitor rates. High loads can also be expected due to large amounts of laundry and maintenance activities (Box 15.2). Hospital wastewater consists of harmful pathogens, metabolites of pharmaceuticals, pesticides, disinfectants and radioactive elements if it is from facilities conducting cancer treatment. According to AERB, India, most radioisotopes used in medical facilities have very short half-lives; therefore, keeping the effluents from such sources in the healthcare facilities in lead coated underground tanks for ten half-lives before discharging them into municipal wastewater mains is required to reduce radioactivity and toxic chemicals. In developing countries like India, the improper disposal of effluents both from hospitals and bulk drug manufacturing units is the major pathway for antibiotics to enter the aquatic environment, one of the primary causes for development of antimicrobial resistance (AMR) (McClellan and Halden 2010).

In India, antibiotic-resistant bacteria and their genes as well as persistent, non-biodegradable hydrophilic chemicals in water bodies, have been reported from different water sources, resulting in the spread of diseases. The major sources are the pharmaceutical wastewaters and hospital effluents that are released into the nearby water bodies without 


\section{Box 15.1 Case study}

\section{The Spinal Injury Centre, New Delhi}

Concerned with falling water levels, and with growing dependence on groundwater, the authorities at the Indian Spinal Injury Centre decided to adopt rainwater harvesting on the hospital premises. Before the system was implemented, the water level in the hospital borewell stood at $32.2 \mathrm{~m}$ below ground level (bgl) in April 2003. The Spinal Injury Centre deployed a rainwater harvesting system that is able to harvest 27,317 cubic metre $\left(\mathrm{m}^{3}\right)$ or $273,17,000$ litres. The rooftop rainwater and the surface runoff from the western part of the building are drained into a storm-water drain that runs to the west side of the building. This water is diverted into a recharge well located at the northwest corner of the campus near an existing borewell. A part of the rooftop rainwater from the east side of the hospital building and runoff from the paved area are diverted through a network of pipes and collection chambers to another stormwater drain that runs to the north of the premises. This runoff is also diverted to the same recharge well located near the borewell. The recharge well is $2.75 \mathrm{~m}$ in length, $2.13 \mathrm{~m}$ in breadth and $1.82 \mathrm{~m}$ deep, with a recharge bore of $100 \mathrm{~mm}$ diameter that led the water table to rise to $20 \mathrm{~m}$ from its previous depth of $36.6 \mathrm{~m}$. The recharge well has two compartments, and the runoff water undergoes two stages of filtering before it enters the recharge borewell. Layers of brickbats and sand ensure the quality of water used for recharging purposes. This project confirmed that it is possible to arrest declining water levels through rainwater harvesting.

Source: CSE, Centre for Environmental Health, 2016

\section{Box 15.2 Case study Aravind Eye Care Hospital, Pondicherry}

Aravind Eye Care Hospital in Pondicherry pumps out $120 \mathrm{~m}^{3}$ of water from a bore well every year, of which $100 \mathrm{~m}^{3}$ of water is recycled using the DEWATS (Decentralized Wastewater Treatment System). The treated water is used in toilets, gardens, for vegetable cultivation and for irrigating the paddy field. The treatment facility receives 270-300 KLD from the hospital building that includes only domestic sewage. As seen in Figure 15.1, the greywater and the black water generated in the hospital premises first enter separate two-chambered settlers. The settlers for black water treatment are 
integrated with the anaerobic baffled reactors. The partially treated black water then undergoes secondary anaerobic treatment. The black water and grey water are collectively passed through anaerobic filters and then to the series of horizontal gravel filters planted with Canna indica. The final treatment is done through polishing ponds where the water is stored for further reuse (Figure 15.2).

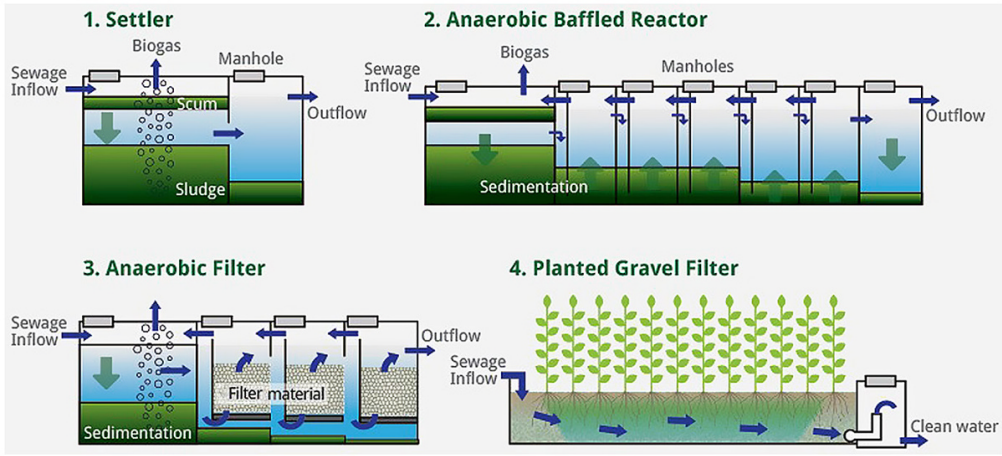

Figure 15.1 Treatment of wastewater at Aravind Eye Hospital.

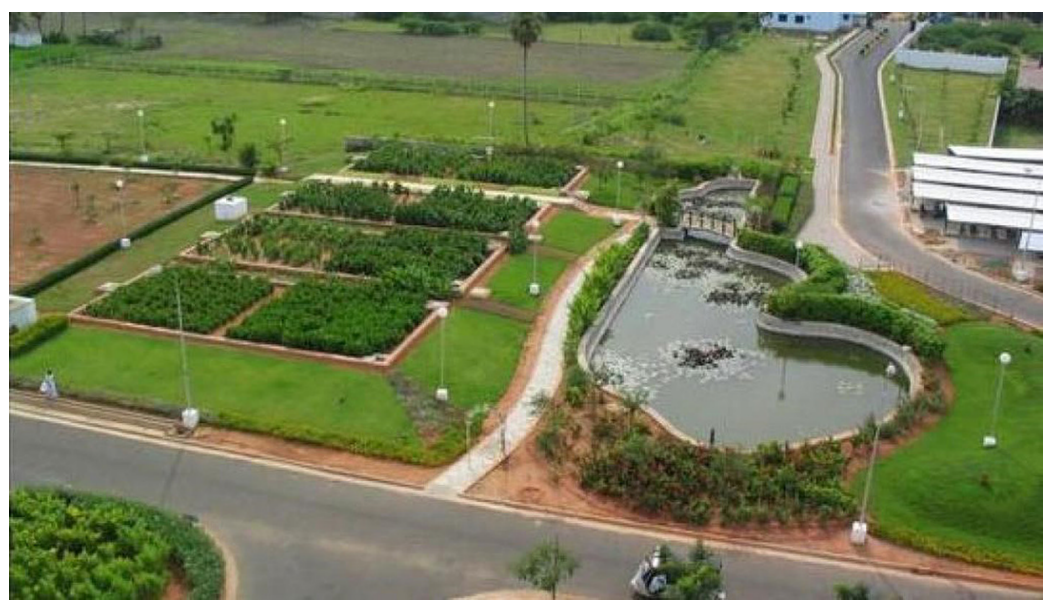

Figure 15.2 A bird's-eye view of the facility.

adequate treatment. The two largest rivers of India - Ganga and Yamuna, receive varying concentrations of drug-resistant bacteria from multiple sources. 


\section{The role of the health sector}

Responses in combating climate adversities, efficient management of water resources and management of emerging disease patterns and conditions are some of the perceived roles of the healthcare sector. Some of these features are described below:

a. Water conservation and effective management in healthcare facilities: Any beneficial reduction in water loss, water use and water wastage can be classified as water conservation. An important component of water conservation involves minimising water losses, prevention of water wastage and increasing efficiency in water use. The Kayakalp scheme outlines the measures that include ensuring adequate quantity of supply of quality water by estimating and providing storage facilities, in-situ treatment and prevention against identified parameters of contaminants, maintenance of supply systems, inspection of wastage through water audits, rainwater harvesting and recycling of wastewater through effluent treatment plants (ETPs), sewage treatment plants (STPs) and hardness removal if required. Various treatment technologies can be installed to decisively remove elemental presence based on regional contaminant profiles.

b. Wastewater recycling and use: Wastewater can be minimised by enhancing water-use efficiency such as installation of automatic turn-off systems in water faucets, preventing and stopping leakages, using efficient flush models in toilets, use of cold loop systems in heating, ventilating, air conditioning (HVAC), on-site wastewater treatment system wherever feasible, recycling wastewater for cooling, toilets and irrigation. Hospital wastewater can be of three types - black water, grey water and storm water. Black water may have faecal matter and urine of patients with or without infectious diseases. Grey water contains residues from washing, bathing, laboratory processes, laundry, kitchen and other technical processes such as cooling water or the rinsing of X-ray films, potentially loaded with genotoxic or cytotoxic agents. Storm water is from rain. This last category consists of water collected from roofs, grounds, yards and paved surfaces, which can be used for irrigating hospital grounds, toilet flushing and other general washing purposes. It may be lost to drains and watercourses, but it is sometimes used for groundwater recharging. The first two categories are the ones that need proper treatment before disposal. Hospitals must explore the usage of suitable wastewater treatment technologies for chemicals and pathogens to reduce pollution and maximise reuse.

c. Preparedness for managing emerging diseases related to water stress and water pollution: Poor water quality and management leading to infectious as well as non-communicable diseases require surveillance; timely detection and early warning of outbreaks. These present a complex challenge to health authorities in India. Water stagnation leading 
to vector-borne diseases like Malaria, Dengue, Chikungunya, Nipah can be prevented through proper utilisation of stormwater and wastewater management. Cleanliness and hygiene using simple soap and water cleaning methods can prevent the spread of debilitating emerging diseases.

\section{Key takeaways}

- While the healthcare system in India is faced with adversities related to erratic climate events, it serves as a key player in managing and mitigating risks to human health. Both events of flood and drought pose a critical threat to the healthcare infrastructure by reducing its ability to function at optimal capacity. Yet it must be resilient to respond to rapid health impacts caused as a result of such events.

- The health sector must optimise its current functions in water-deficient systems by improvising and harnessing currently available technologies while maintaining regular checks and balances as well as reduce its water footprint.

- The healthcare sector is also a major contributor to water-related pollution and this can be neutralised if systems are in place to regularise the in situ management of various contaminants and reuse/sell some of the treated water for non-potable purposes and in sensitive areas.

\section{Notes}

1 Water suitable for drinking belongs to Class A or C. Class A water can be consumed after disinfection and does not require conventional treatment, whereas class $\mathrm{C}$ requires conventional treatment and disinfection before drinking. In Class A water, most probable number (MPN) of coliform bacteria per hundred millilitres of water is 50 or less, $\mathrm{pH}$ is 6.5 to 8.5 and bacterial oxygen demand after 5 days at $20^{\circ} \mathrm{C}$ is $2 \mathrm{mg} / \mathrm{L}$ or less. In Class $\mathrm{C}$ water MPN of coliform bacteria could be up to $5000, \mathrm{pH}$ is between 6 and 9 and $\mathrm{BOD}$ after 5 days is $3 \mathrm{mg} / \mathrm{L}$ or less.

2 High-strength sewage contains greater amounts of fats, oils, and greases (FOG) or other organic components than residential wastewater. It can also refer to effluent containing large quantities of suspended solids or high amounts of certain chemicals, such as disinfectants. Any or all of these components can interfere with the normal biological processes that most onsite systems use.

\section{References}

Bureau of Indian Standards IS 10500. (2012), with Amendment No. 1, June 2015, 11 p. Cann, K. F., Thomas, D. R., Salmon, R. L., Wyn-Jones, A. P., \& Kay, D. (2013). Extreme water-related weather events and waterborne disease. Epidemiology and Infection, 141(4), 671-686. 
Central Groundwater Board, Ministry of Water Resources, Govt. of India. (2018). Groundwater quality in shallow aquifers of India. CGWB. http://cgwb.gov.in/ documents/Waterquality/GW_Quality_in_shallow_aquifers.pdf.

Central Water Commission. (2019). Status of trace and toxic metals in Indian rivers Ministry of Jalshakti, Govt. of India.

Chokshi, M., Patil, B., Khanna, R., Neogi, S. B. Sharma, J. Paul, V. K., \& Zodpey, S. (2016). Health systems in India. Journal of Perinatology, 36. doi: 10.1038/jp.2016.184

Coyte, R. M., Jain, R. C., Srivastava, S. K., Sharma, K. C., Khalil, A., Ma, L., \& Vengosh, A. (2018). Large-scale uranium contamination of groundwater resources in India. Environmental Science \& Technology Letters, 5-6, 341-347.

Dhara, V. R., Schramm, P. J., \& Luber, G. (2013). Climate change \& infectious diseases in India: Implications for health care providers. Indian Journal of Medical Research, 138(6), 847-852.

ENVIS Centre and MOEF. (2019). National status of Wastewater Generation and Treatment. ENVIS Centre and the Ministry of Environment, Forest and Climate Change, Govt. of India. http://www.sulabhenvis.nic.in/database/stst_wastewater_2090.aspx

Govt. of India and Govt. of Netherlands. (2003). Volume 6: Water quality sampling - design manual. http://nhp.mowr.gov.in/Docs/HP-2/Manuals/ManualSWVolume6DesignManualW.pdf.

Hofste, R. W., Reig, P., \& Schleifer, L. (2019). 17 Countries, home to one-quarter of the world's population, face extremely high water stress. World Resources Institute. https:/www.wri.org/insights/17-countries-home-one-quarter-worldspopulation-face-extremely-high-water-stress, World Resources Institute Blog.

Kelkar, S. (2019, September 01). When water kills, India Water Portal, https:// www.indiawaterportal.org/faqs/waterborne.

Kumari, A., Maurya, N. S., \& Tiwari, B. (2020). Hospital wastewater treatment scenario around the globe. Current Developments in Biotechnology and Bioengineering 549-570, doi: 10.1016/B978-0-12-819722-6.00015-8.

McClellan, K., \& Halden, R. U. (2010). Pharmaceuticals and personal care products in archived U.S. Biosolids from the 2001 EPA national sewage sludge survey. Water Research, 44, 658-668.

National Health Portal, Govt. of India. (2018). Health impacts of flooding and risk management. NHP. https://www.nhp.gov.in/health-impacts-of-flooding-and-riskmanagement_pg

Payus, C., Huey, L. A., Adnan, F., Rimba, A. B., Mohan, G., Chapagain, S. K., \& Fukushi, K. (2020). Impact of extreme drought climate on water security in North Borneo: Case study of Sabah. Water, 12(4), 1135, doi: 10.3390/w12041135.

Water Aid India. (2005). Drinking water and sanitation status in India. Water Aid India. WHO. (2011). Guidelines for Drinking Water Quality (4th Ed.). World Health Organisation. https://www.who.int/water_sanitation_health/publications/2011/ 9789241548151_ch10.pdf

WHO. (2014). Safe Management of Wastes from Healthcare Activities (2nd Ed.). WHO. https://www.who.int/water_sanitation_health/publications/2011/ 9789241548151_ch10.pdf. 